\title{
PYROLIGNEOUS LIQUOR EFFECT ON IN AND EX VITRO PRODUTION OF Oeceoclades maculata (Lindl). Lindl. ${ }^{1}$
}

\author{
CARLOS JOSÉ DA SILVA ${ }^{2 *}$, ISANE VERA KARSBURG ${ }^{3}$, POLIANA COQUEIRO DIAS $^{2}$, TATIANA PAULA \\ MARQUES DE ARRUDA ${ }^{3}$
}

\begin{abstract}
Pyroligneous fraction from wood carbonization can be used for several purposes. In this sense, this study aimed to test a pyroligneous liquor extracted during carbonization of forest residues for the vegetative development of the orchid Oeceoclades maculata. The concentrations of pyroligneous liquor used in the treatments were $\mathrm{T} 1=0 \mathrm{~mL} \mathrm{~L}{ }^{-1}, \mathrm{~T} 2=1 \mathrm{~mL} \mathrm{~L}^{-1}, \mathrm{~T} 3=2 \mathrm{~mL} \mathrm{~L}^{-1}, \mathrm{~T} 4=3 \mathrm{~mL} \mathrm{~L}^{-1}, \mathrm{~T} 5=4 \mathrm{~mL} \mathrm{~L}^{-1}$, and $\mathrm{T} 6=5 \mathrm{~mL} \mathrm{~L}^{-1}$. These treatments were tested together with and without activated charcoal for in vitro and ex vitro propagation. In vitro developed protocorms were assessed according to development or not, the presence of fungus, leaves, and roots. For ex vitro evaluations, leaf size, size, the number of roots, total plant height, and the number of buds were assessed. Possible differences between treatments were tested by means of analysis of variance (ANOVA) and Tukey's test at 5\% significance. The use of pyroligneous liquor at low doses was significant in vegetative tissue development as well as for root and leaf formations in $O$. maculata seedlings since it presents all the essential mineral elements to the structural development of these plants.
\end{abstract}

Keywords: Orchid. Vegetative propagation. Pyroligneous acid.

\section{USO DO LICOR PIROLENHOSO NA PRODUÇÃO DE MUDAS IN VITRO E EX VITRO DE Oeceoclades maculata (Lindl). Lindl.}

\begin{abstract}
RESUMO - A fração pirolenhosa obtida com a carbonização da madeira pode ser utilizada para diversos fins. Sendo assim, este trabalho teve por objetivo testar o licor pirolenhoso extraído durante o processo de carbonização de resíduos florestais no desenvolvimento vegetativo da orquídea Oeceoclades maculata. As concentrações do licor pirolenhoso utilizadas nos tratamentos foram: T1 $=0 \mathrm{ml} \cdot \mathrm{L}^{-1}$, T2 $=1 \mathrm{ml} . \mathrm{L}^{-1}$, $\mathrm{T} 3=2 \mathrm{ml} . \mathrm{L}^{-1}, \mathrm{~T} 4=3 \mathrm{ml} . \mathrm{L}^{-1}, \mathrm{~T} 5=4 \mathrm{ml} . \mathrm{L}^{-1}$ e T6 $=5 \mathrm{ml} . \mathrm{L}^{-1}$, esses tratamentos foram testas com e sem carvão ativado no desenvolvimento in vitro e ex vitro da orquídea. As seguintes características dos protocórmos desenvolvidos in vitro foram avaliadas: com fungo, sem desenvolvimento, em desenvolvimento, presença de folhas e raízes. Para o desenvolvimento ex vitro foram avaliados: Tamanho das folhas, tamanho e número de raízes, altura total da planta, quantidade de gemas. Possíveis diferenças entre os tratamentos foram testada por meio de Análise de variância (ANOVA) e teste de Tukey a 5\% de significância. O uso do licor pirolenhoso em dosagem pequenas mostrou-se significativo no desenvolvimento dos tecidos vegetativos e na formação radicular e foliar de Oeceoclades maculata, uma vez que apresenta todos os elementos minerais essenciais ao desenvolvimento estrutural da planta.
\end{abstract}

Palavras-Chave: Orquídea. Propagação vegetativa. Ácido pirolenhoso.

\footnotetext{
${ }^{*}$ Corresponding author

${ }^{1}$ Received for publication in $09 / 15 / 2016$; accepted in $02 / 22 / 2017$.

${ }^{2}$ Departament of Plant Science, Universidade Federal Rural do Semi-Árido, Mossoró, RN, Brazil; carlos.silva@ufersa.edu.br, poliana.coqueiro@ufersa.edu.br.

${ }^{3}$ Faculty of Biological and Agricultural Sciences, Universidade do Estado de Mato Grosso, Alta Floresta, MT, Brazil; isane9@yahoo.com.br, tatianarruda@unemat.br.
} 


\section{INTRODUCTION}

A large number and variety of orchid species can be found in forest ecosystems, being a great attraction for Brazilian and worldwide ornamental markets. Orchids were the first plants of economic importance cloned in vitro, on a commercial scale, with tissue culture techniques assisting in such species preservation. One of the main advantages of this technique is due to the possibility of handling a large number of individuals in a reduced space and under aseptic conditions (VENTURA et al. 2002; UNEMOTO et al. 2007).

Several nutrient media have been used to meet the requirements of in vitro cultivated plants, into which are added compounds according to metabolic, energetic, and structural needs of each cultivated tissue cells (STANCATO; ABREU; FURLANI, 2008; UNEMOTO et al. 2007).

Currently, culture media have been supplemented with liquid phase from carbonization process, known as a pyroligneous liquid, pyroligneous extract, pyroligneous acid, wood vinegar, pyroligneous liquor, liquid smoke, and bio-oil. Pyroligneous liquor is the aqueous fraction of a condensed liquid, brown colored, and composed of at least $80 \%$ water and a range of dozens of chemical components, in particular, acetic acid, methyl alcohol, and acetone. This substance from wood carbonization can be used for different purposes in agriculture such as fertilizers, nematicides, fungicides, and insecticides (PEREIRA; SHAITZA; BAGGIO, 2000; SALVATO et al. 2007;
SAKITA; PORTO; SAKITA, 2007; ALVES et al. 2007).

Several studies have demonstrated the benefits of applying pyroligneous extract to soil or substrates for seedling production of some species. Among these studies, one can cite the evaluations on rice (TSUZUKI; MORIMTSU; MATSUI, 2000), sugarcane (UDDIN et al., 1995), bamboo (SILVA et al., 2006), eucalyptus (WANDERLEY; FARIA; VENTURA, 2012), Rangpur lime (ZANETTI et al., 2004), lettuce (MASCARENHAS et al., 2006a; ROEL et al., 2007), pine seedlings (PORTO; SAKITA; NAKAOKA, 2007), and okra (MASCARENHAS et al., 2006b). However, few studies are found relating the use of pyroligneous liquor and orchid cultivation (SCHNITZER et al., 2010; MIRANDA; VIEIRA; KARSBURG, 2014; SCHNITZER et al., 2015).

Thus, this study aimed to test the use of pyroligneous liquor in in vitro and ex vitro development of seedlings of Oeceoclades maculata (Lindl.) Lindl.

\section{MATERIAL AND METHODS}

We tested $O$. maculata in vitro development using pyroligneous liquor extracted from carbonization Enterolobium contortisiliquum (Vell.) Morong, which was submitted to a nutrient analysis previously. Table 1 shows the chemical analysis with quantification limit values (QLs) of pyroligneous liquor.

Table 1. Chemical components found in Enterolobium contortisiliquum (Vell.) Morong pyroligneous liquor.

\begin{tabular}{ccc}
\hline Parameter & QL & Results \\
\hline Total nitrogen & 0.0100 & $572.58 \mathrm{mg} \mathrm{N} \mathrm{L}^{-1}$ \\
Total aluminum & 0.0130 & $4.9900 \mathrm{mg} \mathrm{Al} \mathrm{L}^{-1}$ \\
Total arsenic & 0.0010 & $\mathrm{ND}$ \\
Total barium & 0.0005 & $\mathrm{ND}$ \\
Total boron & 0.0030 & $\mathrm{ND}$ \\
Total cadmium & 0.0020 & $\mathrm{ND}$ \\
Total calcium & 0.0410 & $19.540 \mathrm{mg} \mathrm{Ca} \mathrm{L}$ \\
Total lead & 0.0100 & $\mathrm{ND}$ \\
Total copper & 0.0013 & $0.3120 \mathrm{mg} \mathrm{Cu} \mathrm{L}^{-1}$ \\
Total chrome & 0.0020 & $1.2540 \mathrm{mg} \mathrm{Cr} \mathrm{L}^{-1}$ \\
Total sulfur & 0.4000 & $79.440 \mathrm{mg} \mathrm{S} \mathrm{L}^{-1}$ \\
Total iron & 0.0012 & $786.40 \mathrm{mg} \mathrm{Fe} \mathrm{L}$ \\
Total phosphorus & 0.0050 & $128.40 \mathrm{mg} \mathrm{P} \mathrm{L}$ \\
Total magnesium & 0.0050 & $3.7490 \mathrm{mg} \mathrm{Mg} \mathrm{L}^{-1}$ \\
Total manganese & 0.0004 & $3.4450 \mathrm{mg} \mathrm{Mn} \mathrm{L}^{-1}$ \\
Total mercury & $\mathrm{ND}$ \\
Total nickel & 0.0010 & $\mathrm{ND}$ \\
Total potassium & 0.0020 & $9.0000 \mathrm{mg} \mathrm{K} \mathrm{L}^{-1}$ \\
Total selenium & 1.0000 & $\mathrm{ND}$ \\
Total sodium & 0.0010 & $112.00 \mathrm{mg} \mathrm{Na} \mathrm{L}$ \\
Total zinc & 0.1000 & $0.2400 \mathrm{mg} \mathrm{Zn} \mathrm{L}^{-1}$ \\
\hline
\end{tabular}

$\mathrm{QL}=$ quantification limit, $\mathrm{ND}=$ not detected. 
Seeds of three mature capsules of $O$. maculata were inoculated in a simplified culture medium composed of $30 \mathrm{~g} \mathrm{~L}^{-1}$ sugar, $2 \mathrm{~g} \mathrm{~L}^{-1}$ fertilizer B\&G, $1 \mathrm{~g} \mathrm{~L}^{-1}$ activated charcoal, $4 \mathrm{~g} \mathrm{~L}^{-1}$ agar, and $100 \mathrm{~mL} \mathrm{~L}^{-1}$ coconut. The $\mathrm{pH}$ was adjusted to 5.8 before adding the pyroligneous liquor to the following treatments: $\mathrm{T} 1=0 \mathrm{~mL} \mathrm{~L}^{-1}, \mathrm{~T} 2=1 \mathrm{~mL} \mathrm{~L}^{-1}$, $\mathrm{T} 3=2 \mathrm{~mL} \mathrm{~L}^{-1}, \mathrm{~T} 4=3 \mathrm{~mL} \mathrm{~L}^{-1}, \mathrm{~T} 5=4 \mathrm{~mL} \mathrm{~L}^{-1}$, and $\mathrm{T} 6=5 \mathrm{~mL} \mathrm{~L}^{-1}$. Six-hundred protocorms of $O$. maculata were used, five of them distributed into vials containing $60 \mathrm{~mL}$ simplified medium. Each treatment comprised 10 vials with 5 protocorms. The same method was performed but without activated charcoal, totaling 120 vials, i.e. 60 containing medium with activated charcoal and the other 60 containing medium without activated charcoal.

Treatments were assessed during 153 days considering the following protocorm characteristics for each treatment: the presence of fungus, development, and presence of leaves and roots. The number of protocorms and vials that presented these characteristics were registered in each observation.

A $2 \times 5$ factorial scheme was used and consisted of culture media with and without activated charcoal and six doses of pyroligneous liquor $\left(0,1,2,3,4\right.$, and $\left.5 \mathrm{~mL} \mathrm{~L}^{-1}\right)$ arranged in a randomized block design with five replications and two vials with five protocorms per plot. Regressions were used to test the significance of all variables: pyroligneous liquor concentration, the presence of activated charcoal, development of leaves and roots in protocorms. Possible differences among treatments were tested using analysis of variance (ANOVA) and Tukey's test at 5\% significance. In addition, significant differences between treatments with and without activated charcoal were assessed using the t-test. All the analyses were performed in R-language (R DEVELOPMENT CORE TEAM, 2011) using Biodiversity R software.

For ex vitro development, seedlings from in vitro development test showing a complete vegetative formation (with leaves and roots) were used. These seedlings were 153 days old and before being inserted into the substrate, they were measured for length of leaves, roots, and overall plant, as well as the number of roots and buds of individuals.

The substrate was composed of peroba bark (Aspidosperma polyneuron Muell. Arg.) and Chilean moss at a $1: 1$ ratio, in $500-\mathrm{mL}$ containers. Six treatments were performed $\left(\mathrm{T} 1=0 \mathrm{~mL} \mathrm{~L} \mathrm{~L}^{-1}\right.$, $\mathrm{T} 2=1 \mathrm{~mL} \mathrm{~L}^{-1}, \mathrm{~T} 3=2 \mathrm{~mL} \mathrm{~L}^{-1}, \mathrm{~T} 4=3 \mathrm{~mL} \mathrm{~L}^{-1}$, $\mathrm{T} 5=4 \mathrm{~mL} \mathrm{~L}^{-1}$, and $\mathrm{T} 6=5 \mathrm{~mL} \mathrm{~L}^{-1}$ ) using different pyroligneous liquor concentrations added in distilled water and, subsequently, into the substrate
(50 $\mathrm{mL}$ for each vial). Ten vials were used for each treatment.

During a 90-day period, three evaluations were performed for each individual. The assessed parameters were plant height, leaf length, root length, number of roots, and number of buds. The experimental design was a randomized block with five replications and two vials containing five protocorms each per plot. The relationship between concentrations of pyroligneous liquor and the assessed variables was tested by means of regression equations. Possible differences among treatments were evaluated by means of analysis of variance (ANOVA) and Tukey's test at 5\% significance.

\section{RESULTS AND DISCUSSION}

The response of in vitro grown protocorms to pyroligneous liquor concentrations and to activated charcoal presence showed a third-degree polynomial trend for all the assessed characteristics (Figure 1). The F-test showed a significant interaction $(p<0.05)$ among the tested factors for protocorm with leaves, the presence of roots, and developing protocorms (Figure 1). This outcome stresses different protocorm responses to each concentration of pyroligneous liquor and to the presence of activated charcoal in the culture medium.

Regardless the pyroligneous liquor concentration, no significant influence was observed in charcoal addition to culture medium when assessing the number of protocorms with leaves and number of developing individuals. Protocorms cultivated in presence of activated charcoal showed improved development and a larger number of leaves if compared to those in medium without this antioxidant (Figure 1). These results might have occurred due to the adsorption of toxic substances by activated charcoal during culture medium autoclaving, by seedling tissues throughout cultivation, or by toxic products from pyroligneous acid.

When testing the interaction between activated charcoal and pyroligneous liquor doses, by regression analysis, we noted a marked negative effect on all pyroligneous liquor concentrations for media without activated charcoal addition (Figure 1), showing differences in the number of developing protocorms. On the other hand, the presence of activated charcoal caused a reduced number of roots for treatments with 3 and $4 \mathrm{~mL} \mathrm{~L}^{-1}$ pyroligneous liquor (Figure 1). 
A

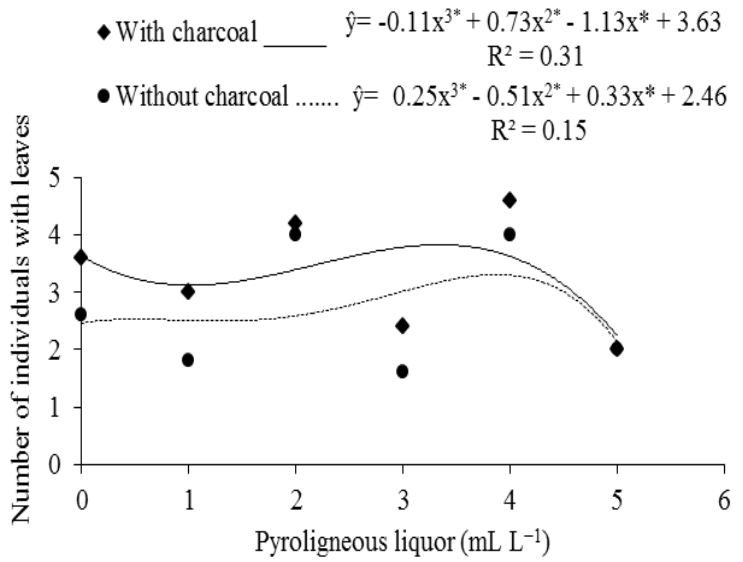

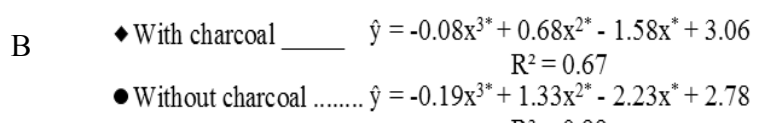

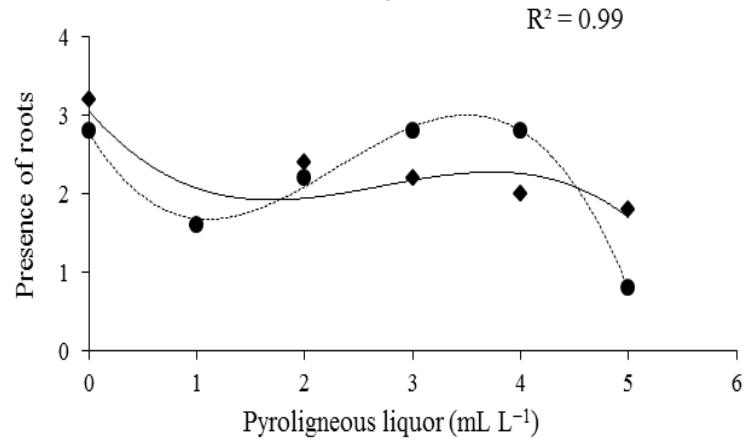

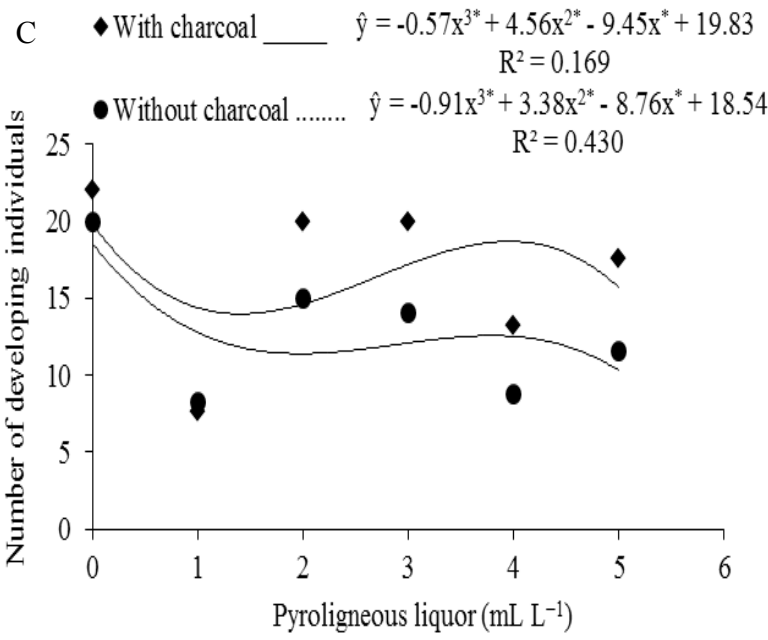

Figure 1. Protocorms of Oeceoclades maculata (Lindl.) with leaves (A), with roots (B), and development (C) grown in culture medium with and without activated charcoal, and submitted to different pyroligneous liquor concentrations $(0,1,2$, 3,4 , and $\left.5 \mathrm{~mL} \mathrm{~L}^{-1}\right) *$ significant at $5 \%$, ns $=$ not significant at $5 \%$ by the F-test.

Activated charcoal addition to the culture medium is a common practice in in vitro cultivation of orchids, being a beneficial component by promoting increases in plant height and rooting for some species (CHAPLA et al., 2009; PACEK-BIENIEK; DYDUCH-SIEMIŃSKA; RUDAŚ, 2010). Such influence might be attributed to the adsorption of inhibitory substances from culture medium or toxic products released by explants, as well as the maintenance of a $\mathrm{pH}$ at optimum value for morphogenesis (VILLA; PASQUAL; SILVA, 2014).

However, the effects of activated charcoal are highly dependent on the plant species, organ, and genotype under study; besides, charcoal source and purity and degree of activation also have great influence on that (VILLA; PASQUAL; SILVA, 2014). The often-inhibitory effect on growth, observed for treatments with activated charcoal, may be due to the adsorbent property of activated charcoal so that acting as both growth promoter and inhibitor. This is attributed to an excellent pore network with a great internal surface of the activated charcoal, wherein several culture-medium inhibitory substances or toxic products released by explants can remain adsorbed (CHAGAS et al., 2005; THOMAS, 2008). As a result, this compound adsorbs not only toxic compounds but also essential nutrients to plant growth, which are released slowly (GUSON; MORAES; RONCONI, 2012; VILLA; PASQUAL; SILVA, 2014). Therefore, it might explain the low root production in media with activated charcoal observed here.

Regardless the activated charcoal use, the concentration of $2 \mathrm{~mL} \mathrm{~L}^{-1}$ pyroligneous liquor may be beneficial to in vitro culturing of $O$. maculata. Conversely, concentrations above $3 \mathrm{~mL} \mathrm{~L}^{-1}$ and below $2 \mathrm{~mL} \mathrm{~L}^{-1}$ had inferior results for the assessed characteristics (Figure 1). As such, O. maculata protocorms absorbed higher contents of nutrients under the influence of pyroligneous liquor at concentrations between 2 and $3 \mathrm{~mL} \mathrm{~L}^{-1}$ since seedlings in these media had an enhanced development.

For protocorms with leaves, a significant difference was observed for media containing activated charcoal at most of the pyroligneous liquor concentrations, except for $5 \mathrm{~mL} \mathrm{~L} \mathrm{~L}^{-1}$. The concentrations of 0,2 , and $4 \mathrm{~mL} \mathrm{~L}^{-1}$ presented the highest number of protocorms with leaf formation. 
For media without activated charcoal, leaf development was higher at the concentrations of 0,2 , and $4 \mathrm{~mL} \mathrm{~L}^{-1}$ (Figure 1). Protocorms with roots reached a great development in treatments without activated charcoal, mainly at 2 and $4 \mathrm{~mL} \mathrm{~L}^{-1}$; whereas, media with charcoal had great development at 0,2 , and $3 \mathrm{~mL} \mathrm{~L}^{-1}$. Among all treatments, control $\left.(0 \mathrm{~mL} \mathrm{~L})^{-1}\right)$ was the one that most favored the root development (Figure 1). Similar results were found for other orchid species, among which $2.5 \mathrm{~mL} \mathrm{~L}^{-1}$ was the best concentration of pyroligneous liquor to be added to culture medium (DAMASCENO et al., 2009).

Plant structural development is directly related to absorption and incorporation of mineral nutrients (SCHNEIDERS et al., 2012). Macro and micronutrient availability in pyroligneous liquor (Table 1) may have contributed to vegetative growth when present in the culture medium at low levels. These nutrients are essential in the organic compound constitution, acting at all plant growth phases such as storage and transfer of energy, cell division, cell elongation, growth, flowering, and fruiting. Thus, minerals present in pyroligneous acid can help the development of protocorms of $O$. maculata cultivated in vitro when the acid is at low concentrations in the culture medium.

Solid media, which inhibits phosphorus, potassium, and zinc diffusion, combined with activated charcoal can inhibit leaf and root formations given the lack of these elements, which are required for organ formation. Zinc plays an important role for seedling metabolism and growth; according to some authors, its availability must be increased in culture medium for an enhancement of orchid in vitro growth (RODRIGUES et al., 2010). In this study, pyroligneous liquor may have acted as a nutrient source for protocorms due to its concentration of macro and micronutrients (Table 1). On the other side, at high concentrations, this substance may have made the culture medium toxic, affecting vegetative propagules (Figure 1).

Fungus proliferation was observed only in two samples from treatments with 2 and $3 \mathrm{~mL} \mathrm{~L}^{-1}$, being thus discarded since development failed, and becoming unviable protocorms. The liquor fungicide action was not tested here; however, fungal occurrences were registered. Interestingly, there was a low incidence of fungi in samples; however, it is unclear if the pyroligneous liquor inhibited microorganism development. Although the pyroligneous liquor presents little inhibition for molding fungi, it would be incorrect to state its absence of fungicide effect since specific tests are required for this assertion (COSTA, SILVA, ESCUDERO, 2003).

In ex vitro vegetative propagation, $O$. maculata seedlings showed a decreasing linear trend as a function of the pyroligneous liquor concentration applied into irrigation water regarding plant height, leaf length, root length, and number of roots, 30 days after experiment installation (Figure 2 ). A second-degree polynomial behavior was found for number of buds. Differently, significant differences were observed between treatments with respect to plant height, leaf length, largest root length, and the number of buds (Figures 1, 2 and 3).

Plant height differed among treatments as detected by the analysis of variance. In contrast, significant differences were found by the Tukey's test only between 0 and $2 \mathrm{~mL} \mathrm{~L}^{-1}$ as well as between 0 and $4 \mathrm{~mL} \mathrm{~L}^{-1}$. The analysis of variance for leaf length was significant between the concentrations of 0 and $2 \mathrm{~mL} \mathrm{~L}^{-1}$ (Figure 2). For leaf length, the analysis of variance also detected significant differences by the Tukey's test between treatments with concentrations of 0 and $4 \mathrm{~mL} \mathrm{~L}^{-1}, 0$ and $5 \mathrm{~mL} \mathrm{~L}^{-1}, 1$ and $4 \mathrm{~mL} \mathrm{~L}^{-1}$, and 1 and $5 \mathrm{~mL} \mathrm{~L}^{-1}$ (Figure 2).

Considering the number of buds, the highest value was registered for the addition of $1 \mathrm{~mL} \mathrm{~L}^{-1}$ pyroligneous liquor, whereas the lowest effect for $5 \mathrm{~mL} \mathrm{~L}^{-1}$. Significant differences were noted by the Tukey's test between the treatments 1 and $5 \mathrm{~mL} \mathrm{~L}^{-1}$ and between 3 and $5 \mathrm{~mL} \mathrm{~L}^{-1}$ (Figure 2). An increased budding can be regarded as important for orchid trade since the numbers of leaves and flowers are directly related to the number of buds. Similar results were observed for orchids of the species Cattleya intermedia and C. loddigesii (SCHNITZER et al., 2010), thus increasing the number of sprouts what directly reflects on flower numbers. The results obtained with $C$. loddigesii also demonstrate that pyroligneous extract use in propagation substrates can favor seedling production (SCHNITZER et al., 2015). Likewise, other studies have demonstrated that this substance may favor rooting and leaf development in ex vitro propagation of orchids (PORTO; SAKITA; NAKOAKA, 2007).

In addition, other studies have demonstrated that pyroligneous extract incorporated into the substrate may lead to main root elongation, increased volume of secondary roots, and provide a satisfactory early germination and development of Anadenanthera macrocarpa (SAKITA; PORTO; SAKITA, 2007). By contrast, applications in corn led to small variations in soil fertility, being insufficient for changes in plant growth (ALVES et al., 2007). In this study, ex vitro vegetative propagation of $O$. maculata was favored when $1 \mathrm{~mL} \mathrm{~L}^{-1}$ pyroligneous liquor was added to irrigation water, being most effective for overall plant development. Notwithstanding, the other concentrations of pyroligneous liquor were adverse to seedling development. As a result, we may state that high concentrations of this substance inhibit plant growth due to toxic effects associated with acids present in the liquor, as well as mineral elements at high concentrations such as iron (Table 1). 

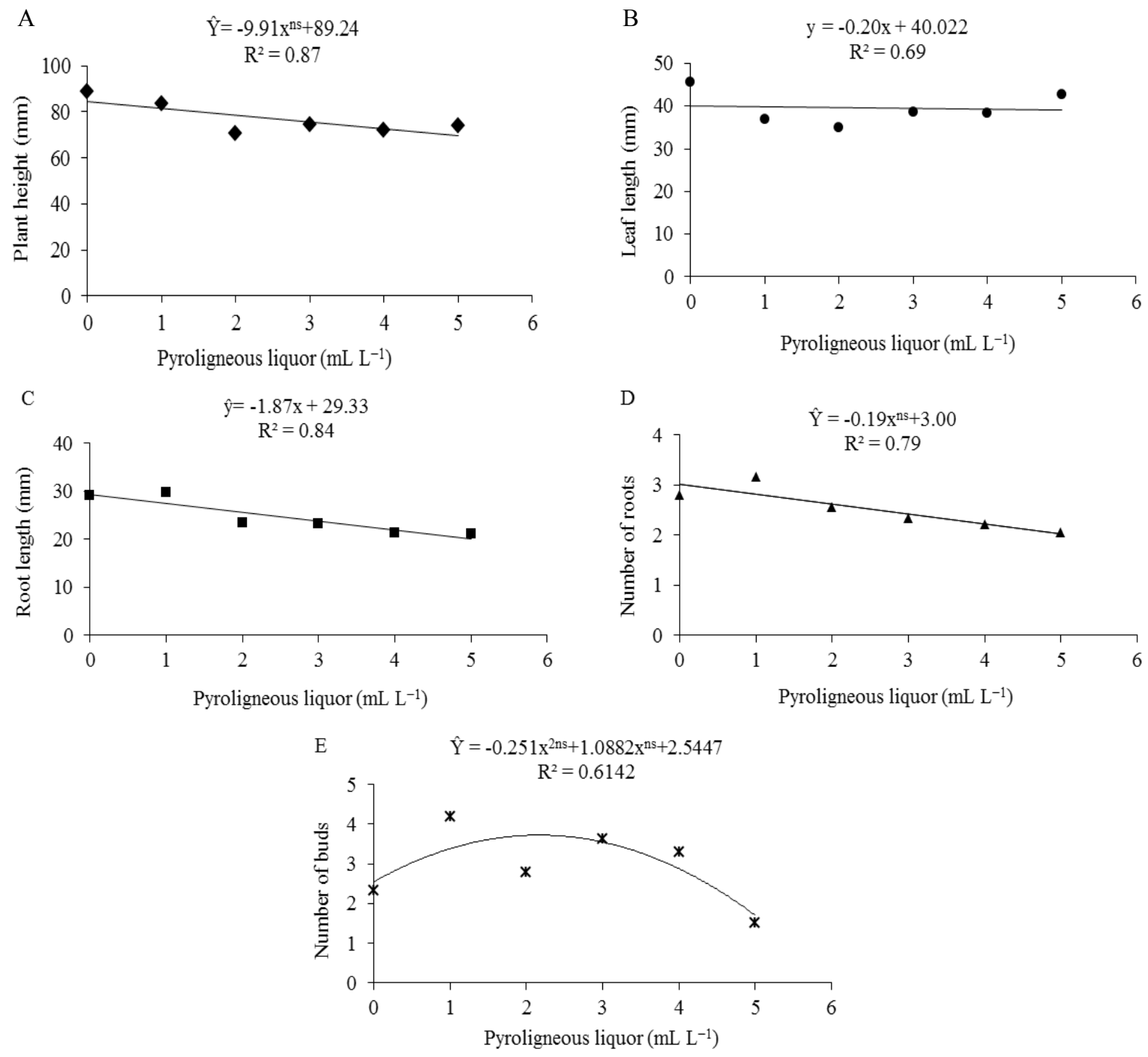

Figure 2. Plant height (A), leaf length (B), root length (C), number of roots (D), and number of buds (E) of seedlings of Oeceoclades maculata (Lindl). Lindl. three months after ex vitro development and submitted to different irrigation treatments: water and water solution with $1,2,3,4$, and $5 \mathrm{~mL} \mathrm{~L}^{-1}$ pyroligneous liquor. $*=$ significant at $5 \%$, ns $=$ not significant at $5 \%$ by the F-test.
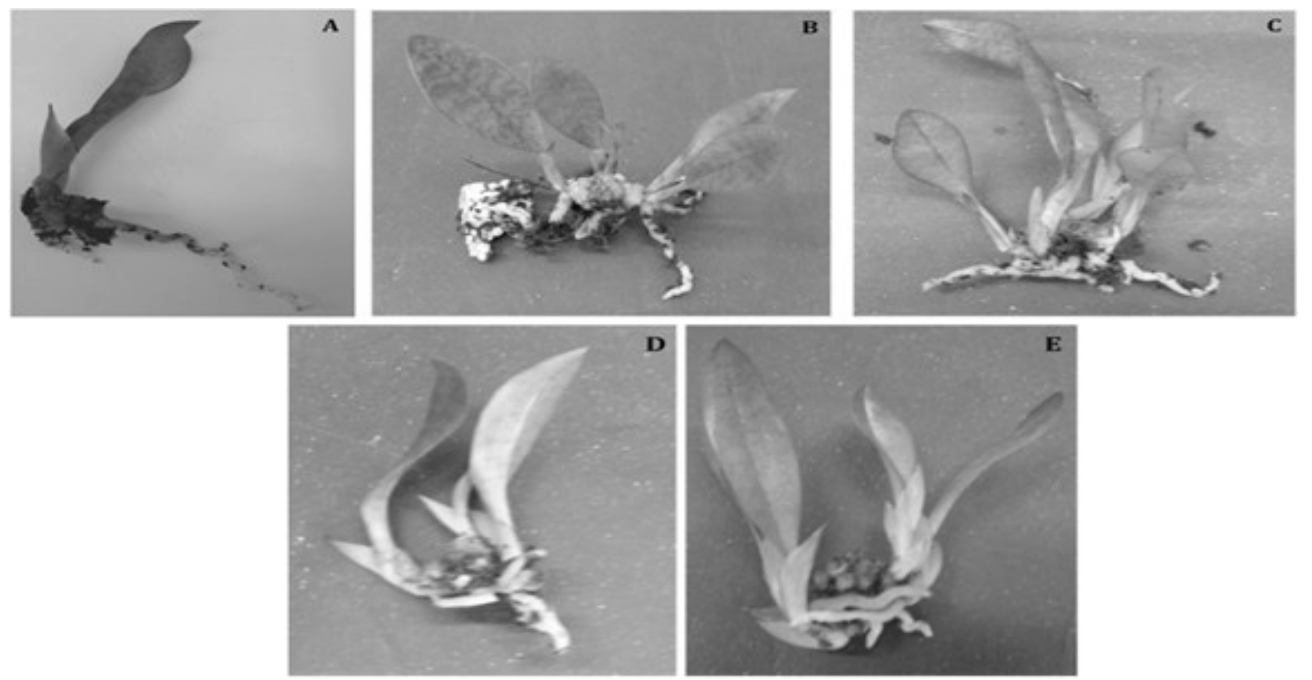

Figure 3. Seedlings of Oeceoclades maculata (Lindl). Lindl. after three months of ex vitro development in a substrate composed of peroba bark and sphagnum (1:1) irrigated with water (A) and water solutions with 1, 2 (C), 3 (D), 4 (E), and $5 \mathrm{~mL} \mathrm{~L}^{-1}$ (E) of pyroligneous liquor. 


\section{CONCLUSIONS}

At small doses, pyroligneous liquor had significant results for vegetative tissue development, rooting, and leaf formation of Oeceoclades maculata both in vitro and ex vitro since all essential mineral elements were made available to plant structural development. Inversely, higher doses of this liquor inhibited the vegetative development of $O$. maculata due to toxic effects.

\section{REFERENCES}

ALVES, M. et al. Ação de diferentes preparações de extrato pirolenhoso sobre Brevipalpus phoenicis (Geijeskes). Revista Brasileira de Fruticultura, Jaboticabal, v. 29, n. 2, p. 382-385, 2007.

CHAGAS, E. A. et al. Cultivo de embriões imaturos de citros em diferentes concentrações de carvão ativado e ácido giberélico. Ciência e Agrotecnologia, Lavras, v. 29, n. 6, p. 1125-1131, 2005.

CHAPLA, P. I. et al. PH, carvão ativado e agentes geleificantes do meio de cultura no crescimento in vitro de Miltonia flavescens Lindl. Plant Cell Culture \& Micropopagation, Lavras, v. 5, n. 2, p. 87-93, 2009.

COSTA, A. F.; SILVA, G. F.; ESCUDERO, M. C. Estudo comparativo entre produtos químicos preservantes e licores pirolenhosos na inibição de fungos em boloradores. Brasil Florestal, Brasília, v. 21, n. 75 , p. 23-29, 2003.

DAMASCENO, J. O. et al. Influência do extrato pirolenhoso no desenvolvimento in vitro de orquídeas. In: CONGRESSO BRASILEIRO DE FLORICULTURA E PLANTAS ORNAMENTAIS, 17, 2009, Aracaju. Anais... Aracaju: SBFPO, 2009. 1.CD-ROM.

GUSON, R. R.; MORAES, C. P.; RONCONI, C. C. Influência de diferentes concentrações de carvão ativado no crescimento e enraizamento in vitro de Cattleya pumila HOOK. Agronegócios e Meio Ambiente, Maringá, v. 5, n. 3, p. 551-563, 2012.

MASCARENHAS, M. H. T. et al. Efeito da utilização do extrato pirolenhoso na pro-dutividade do alface. Revista Brasileira de Horticultura, Jaboticabal, v. 24, n. 1, p. 3122-3125, 2006 a.

MASCARENHAS, M. H. T. et al. Efeito da utilização do extrato pirolenhoso na produtividade do quiabeiro. Revista Brasileira de Horticultura, Jaboticabal, v. 24, n. 1, p. 3126-3128, 2006 b.
MIRANDA, D. P.; VIEIRA, A.; KARSBURG, I. V. Crescimento in vitro de Catasetum $\mathrm{x}$ apolloi BENELLI \& GRADE (ORCHIDACEAE) em meio de cultura com adição de licor pirolenhoso de teca (Tectona grandis). Enciclopédia biosfera, Goiânia, v. 10, n. 18, p. 1140-1148, 2014.

PACEK-BIENIEK, A.; DYDUCH-SIEMIŃSKA, M.; RUDAŚ, M. Influence of activated charcoal on seed germination and seedling development by the asymbiotic method in Zygostates grandiflora (Lindl.) Mansf. (Orchidaceae). Folia Horticulturae, Krakow, v. 22, n. 2, p. 45-50, 2010.

PEREIRA, J. C. D.; SHAITZA, E. G.; BAGGIO, A. J. Propriedades Físicas e Químicas e rendimentos da Destilação Seca da Madeira de Grevillea robusta. Colombo: Embrapa Floresta, 2000. 10 p.

PORTO, P. R.; SAKITA, A. E. N; NAKAOKA, S. M. Efeito da aplicação do extrato pirolenhoso na germinação e no desenvolvimento de mudas de Pinus elliottii var. Elliottii. IF-Série Registros, São Paulo, v. 3, n. 31, p. 15-19, 2007.

R DEVELOPMENT CORE TEAM. R: A language and environment for statistical computing. $R$ Foundation for Statistical Computing, Vienna, Austria. ISBN 3-900051-07-0, URL http://www.Rproject.org/, 2011.

RODRIGUES, D. T. et al. Response of Epidendrum Ibaguense (orchidaceae) to the application of lime rates to the pot. Revista Brasileira de Ciência do Solo, Viçosa, v. 34, n. 3, p. 793-800, 2010.

ROEL, A. R. et al. Avaliação de fertilizantes orgânicos na produção de alface em Campo Grande, MS. Scientia Agraria, Curitiba, v. 8, n. 3, p. 325-329, 2007.

SAKITA, A. E. N.; PORTO, P. R.; SAKITA, M. N. Utilização do Extrato Pirolenhoso na Germinação e no Desenvolvimento Inicial de Mudas de Anadenanthera macrocarpa (Benth.) Brenan. IF-Série Registros, São Paulo, v.3, n. 31, p. 57-61, 2007.

SALVATO, N. A. et al. Efeito do Licor Pirolenhoso sobre Lamellaxis gracilis. Revista Científica da FAMINAS, Belo Horizonte, v. 3, n. 1, p. 149-162, 2007.

SCHNEIDERS, D. et al. Germinação, crescimento e desenvolvimento in vitro de orquídeas (Cattleya spp., Orchidaceae). Revista Ceres, Viçosa, v. 59, n. 2 , p. 185-191, 2012.

SCHNITZER, J. A. et al. Substratos e extrato pirolenhoso no cultivo de orquídeas brasileiras 
(Cattleya intermedia (John Lindley) e Miltonia clowesii (John Lindley) (Orchidaceae). Acta Scientiarum Agronomy, Maringá, v. 32, n. 1, p. 139-143, 2010.

SCHNITZER, J. A. et al. Doses de extrato pirolenhoso no cultivo de orquídea. Revista Ceres, Viçosa, v. 62, n. 1, p. 101-106, 2015.

SILVA, A. S. et al. Qualidade de mudas de Eucalipto tratadas com extrato pirolenhoso. Revista Cerne, Lavras, v. 12, n. 1, p. 19-26, 2006.

STANCATO, G. C.; ABREU, M. F.; FURLANI, A. M. C. Crescimento de orquídeas epífitas in vitro: adição de polpa de frutas. Bragantia, Campinas, v. 67, n. 1, p. 51-57, 2008.

THOMAS, T. D. The role of activated charcoal in plant tissue culture. Biotechnology Advances, Kerala, v. 26, n. 6, p. 618-631, 2008.

TSUZUKI, E.; MORIMTSU, T.; MATSUI, T. Effect of chemical compounds in pyroligneus acid on root growth in rice plants. Japanese Journal Crop Science, Tohoku, v. 66, n. 4, p. 15 16, 2000.

UDDIN, S. M. M. et al. Effects of the mixture of charcoal with pyroligneous acid on dry matter production and root growth of summer planted sugarcane (Saccharum officinarum L.). Japanese Journal of Crop Science, Tohoku, v. 64, n. 4, p. 747-753, 1995.

UNEMOTO, L. K. et al. Propagação in vitro de orquídeas brasileiras em meio de cultura simplificado. Revista Brasileira Agrociência, Pelotas, v. 13, n. 2, p. 267-269, 2007.

VENTURA, G. M. et al. Organogênese in vitro a partir de gemas apicais e auxiliares de plantas adultas de orquídeas do grupo Cattleya. Revista Ceres, Viçosa, v. 49, n. 286, p. 613-628, 2002.

VILLA, F.; PASQUAL, M.; SILVA, E. F. Micropropagação de híbridos de orquídea em meio knudson com adição de vitaminas do meio ms, benzilaminopurina e carvão ativado. Semina: Ciências Agrárias, Londrina, v. 35, n. 2, p. 683-694, 2014.

WANDERLEY, C. S.; FARIA, R. T.; VENTURA, M. U. Chemical fertilization, organic fertilization and pyroligneous extract in the development of seedlings of areca bamboo palm (Dypsis lutescens). Acta Scientiarum Agronomy, Maringá, v. 34, n. 3, p. $163-167,2012$.

ZANETTI, M. et al. Influência do extrato pirolenhoso na calda de pulverização sobre o teor foliar de nutrientes em Limoeiro 'Cravo'. Revista Brasileira de Fruticultura, Jaboticabal, v. 26, n. 3, p. 529-533, 2004. 